\title{
Multi-Criteria Evaluation of Port Competitiveness in West Africa Using Analytic Hierarchy Process (AHP)
}

\author{
George Kobina van Dyck ${ }^{1}$, Hawa Mohamed Ismael² \\ ${ }^{1}$ School of Economics and Management, Shanghai Maritime University, Shanghai, China \\ ${ }^{2}$ Scientific Research Academy, Shanghai Maritime University, Shanghai, China \\ Email: kobivandyck@yahoo.com, hawi med ismael@hotmail.com
}

Received 21 May 2015; accepted 26 June 2015; published 29 June 2015

Copyright (C) 2015 by authors and Scientific Research Publishing Inc.

This work is licensed under the Creative Commons Attribution International License (CC BY). http://creativecommons.org/licenses/by/4.0/

c) (7) Open Access

\begin{abstract}
In the last decade, inter-port competition in West Africa has become fiercer as captive hinterlands of ports continue to overlap and become contestable or shared. This is due to door-to-door supply chain services being offered by shipping lines and third party logistics service providers through inter-modalism. In addition, as cargo becomes more concentrated in the region, there have been calls for the selection of a hub location for shipping lines serving the region in order to exploit economies of scale. This paper therefore aims to evaluate the competitiveness of major ports in the West African region based on criteria selected by experts. Using the Analytic Hierarchy Process, port competitiveness was evaluated and ports ranked according to the total weights obtained based on the different criteria used. The Port of Abidjan emerged the most competitive port in West Africa with its strongest links being its efficiency and performance, infrastructure and political stability outlook in spite of recent political turmoil. The Lagos Port Complex, West Africa's largest port in terms of scale and throughput, emerged fifth falling behind the Ports of Lomé, Tema and Dakar respectively owing largely to its political stability outlook. The least competitive port was the Port of Cotonou in Benin.
\end{abstract}

\section{Keywords}

Port Competitiveness, West Africa, Analytic Hierarchy Process, Multi-Criteria Decision Making

\section{Introduction}

Ports have continued to evolve over the last two centuries. In the 19 th century, ports were only seen as means to

How to cite this paper: Dyck, G.K. and Ismael, H.M. (2015) Multi-Criteria Evaluation of Port Competitiveness in West Africa Using Analytic Hierarchy Process (AHP). American Journal of Industrial and Business Management, 5, 432-446.

http://dx.doi.org/10.4236/ajibm.2015.56043 
control markets and therefore there existed little competition and efficiency concerns. Ports then began to compete with each other as they were seen as the last node in reducing costs and increasing efficiency, such competition being spearheaded by the gains in ocean productivity over the past several decades [1]. Growth in international trade, the liberalization of transport markets and concentration in the shipping industry have led to increased port competition worldwide [2]. In recent years, there has been a shift in competition between ports and other actors in the maritime transport sector, to a competitive struggle among global maritime logistics chains [3] of which ports play a pivotal role. Supporting this assertion, [2] states that "port services are no longer provided in isolation, but need to fit in door to door supply chains". A port can be said to be in a competitive position when port users are presented with a competitive offering relative to other connected ports. Therefore, the competitive nature of a port can be said to be dependent on its distinguishing factors and has become dependent on many variables which may be policy-related, terminal-specific, chain-related or scope-related [4]. In a competitive port environment, determining the key factors that guide users in choosing a specific port is imperative as this knowledge used strategically can assist a port in growing and increasing its market share.

This paper therefore aims to evaluate the competitiveness of ports in the West African sub-region. West Africa is characterized by a number of relatively small ports that spread across the West African Atlantic coast. A number of ports are fiercely competing for cargo especially volumes destined for the contestable hinterland of landlocked West Africa. Ports are also competing for hub port status for the region; a move directed at capturing transshipment cargo as West African containerized cargo becomes more concentrated. In the past, West African ports were generally service ports and therefore under full government control. However, the effects of globalization and increased trade have pushed governments and port authorities in the region towards accommodating private sector investment in the form of concessions and moves towards privatization. West African ports are therefore modernizing their facilities and expanding [5] [6]—a move towards increasing their competitiveness and attracting more cargo as hinterlands become increasingly contestable and less captive.

This study focuses on six major West African ports in terms of throughput. They include the ports of Dakar (Senegal), Abidjan (Ivory Coast), Tema (Ghana), Lomé (Togo), Cotonou (Benin) and Lagos (Nigeria). In order to evaluate the competitiveness of these ports, the paper first delves into the demand for maritime container traffic services in West Africa. Then, literature is reviewed to identify the determinants of port competiveness. The information obtained is tested and evaluated by obtaining expert judgment from various respondents in West Africa through an extensive interview process. The relative competitiveness of each port is determined and analysed by using the framework of the Analytic Hierarchy Process.

\section{West African Ports and Demand for Maritime Container Services}

Nearly four million containers were transported in West Africa (Figure 1) in 2012 [5]. This is quite remarkable especially considering that container throughput for the region has been growing at an average rate of $10 \%$ per annum from 2002 to 2012. This growth rate illustrates the dynamism of West Africa and its potential. Although historically container traffic development in the region has been hampered by unreliability of port operations, infrastructure improvements and modernization of ports in addition to port concessions have all contributed to these recent developments [7].

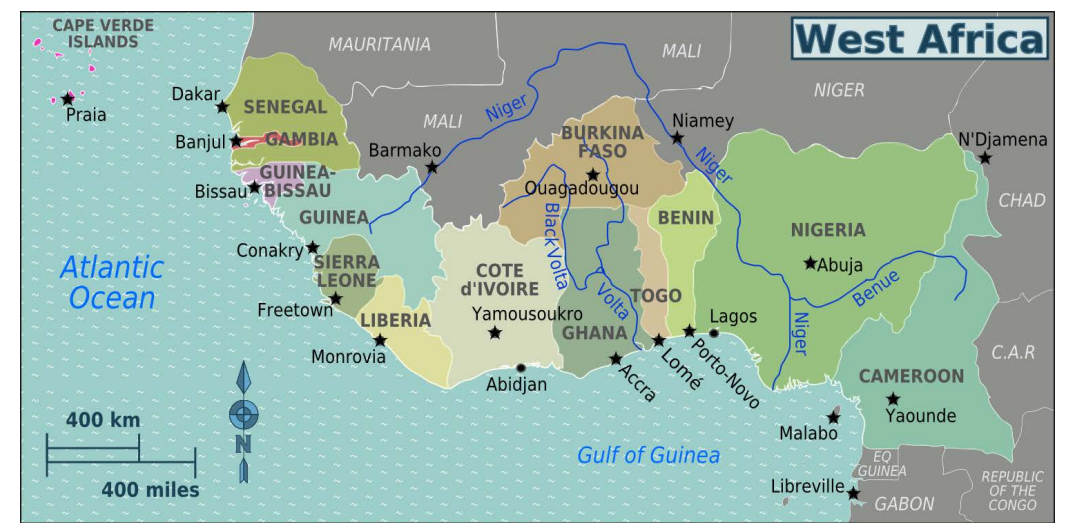

Figure 1. Map of West Africa. 


\section{Maritime Container Services for Ports in West Africa}

There are several container services for ports in West Africa (Table 1). The ratio of direct to feedering services is $60 \%$ to $40 \%$ respectively [7]. Maritime transport is demand driven and it is well documented that developments in the global economy and trade directly affect the demand for maritime transport services. There is a clear link between development in trade and global economic health as trade generally grows more quickly than economic health. This particular fact applies to the West African sub-region as well. The GDP elasticity of maritime container traffic for the region clearly illustrates the changes in port container traffic demand based on the GDP of West African countries. The GDP elasticity of maritime container traffic can be said to be the level of responsiveness of the change in maritime container traffic to the change in GDP.

Figure 2 shows the economic performance of the West African states (in which the ports under study are located) has seen an average annual change of about 5\% per annum for the period 2003-2012. The demand for containers (evidenced by container throughput for ports measured in twenty-foot equivalent units (TEUs)) has increased by about $10 \%$ per annum during the same period. The demand for maritime container transport services is GDP elastic since an increase in GDP by $1 \%$ has lead to an increase in the demand for containers by $2.29 \%$. This implies that change in GDP has a relatively large effect on the changes in the demand for maritime container transport services in West Africa.

\section{Port Competition and Selection from Literature}

Productivity within which a nation uses its human, capital and natural resources determines its competitiveness [8]. In defining port competition, [9] asserts that all relevant aspects connected with ports and competition need to be included in the definition. The authors state that:

"Sea port competition refers to competition between port undertakings, or as the case may be, terminal operators in relation to specific transactions. Each operator is driven by the objective to achieve maximum growth in relation to goods handling, in terms of value added or otherwise. Port competition is influenced by (1) specific demand from consumers, (2) specific factors of production, (3) supporting industries connected with each operator, and (4) the specific competencies of each operator and their rivals. Finally, port competition is also affected by port authorities and other public bodies".

Therefore, factors that affect a port's competitive position can be grouped into two; factors that are within the port's capacity to control and factors outside the bounds of the port's control. Controllable factors may include productivity, port charges and services. On the other hand, non-controllable factors may include local market size, global transportation environment and national transportation policies.

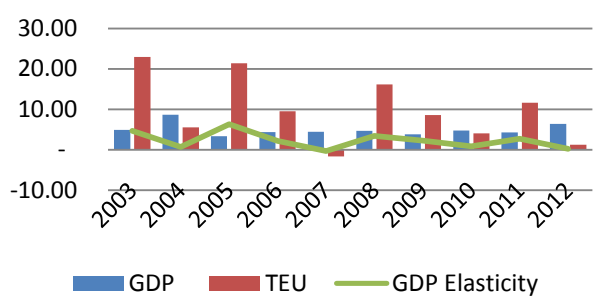

Figure 2. GDP elasticity of container traffic for West Africa.

Table 1. Types of container services for West Africa (source: [7]).

\begin{tabular}{ccc}
\hline Origin & Destination & Description/type of service \\
\hline West African Port & Ports in West Africa & Local feeder of cabotage services \\
Transshipment hub & Ports in West Africa & $\begin{array}{c}\text { Feeder services from transshipment location } \\
\text { (Las Palmas, Algeciras and Tangier Med) }\end{array}$ \\
North and South Europe, Mediterranean & Ports in West Africa & Direct lines \\
Asia & Ports in West Africa & Direct lines \\
North and South America & Ports in West Africa & Direct lines
\end{tabular}


Conducting a survey of port users and freight forwarders for the transatlantic container trade, [10] found that the most important elements in port selection are the number of voyages, inland freight rate, inland intermodal connectivity of the port and the existence and availability of container facilities. Similarly, conducting a survey of companies purchasing shipping services in RO/RO ferry trade in order to study the potential determinants of port choice, [11] found that such factors may be both quantitative and qualitative. Quantitative factors included route factors, and costs and service factors whilst qualitative factors included flexibility and ease of use, marketing strategies of the port, personal contacts and the level of cooperation developed between the shipper and the port. Port competition and/or selection has been noted to be closely related to the ports' location and throughput which in turn, affects direct port calls of shipping companies [12]. In terms of cargo throughput, [13] noted that transshipment and intermodal cargo were the crucial factors to improve port competition. The author concluded that transshipment cargoes make container ports increasingly larger, and helps ports to attract shipping lines from neighboring competing ports.

Likewise, [14] proposed two critical factors regarded influential to port competition; port location and network strategies. They authors assert that ports enjoy an advantage in the negotiating stage with their customers if they are located at prime locations. Taking a different perspective, [15] analysed port choice behavior from the shipper's perspective in Taiwan. The results of their analysis suggest that travel time and cost are the most significant variables. Similarly, [16] examined the shippers' port and carrier selection problem using a discrete choice model. The authors concluded that the most important factors are the distance of the shipper from port, distance to destination (in case of exports), distance from origin (in case of imports), port congestion, and shipping line's fleet size. For evaluation of port service quality, [17] investigated major criteria and sub criteria in broad terms, and suggested seven major criteria and thirty sub-criteria. Major criteria included ready information availability of port-related activities, port location, port turnaround time, available facilities, port management, customer convenience and port costs.

Using the Analytic Hierarchy Process method [18] analysed liner transshipment port selection. The study revealed that handling cost, proximity to main navigation routes and import export areas, condition of infrastructure and feeder network are important service attributes of transshipment ports. Stressing on differentiation strategies, [19] stated that nowadays commercial sea ports have been losing the 'loyalty' of their traffic and have to establish new strategies for securing customer loyalty. In this respect, they suggested two important factor groups i.e., one concerned with commercial factors and the other dealing with technological factors. They argued that the former consisted of the level of infrastructure, transport networks, logistics services, level of port operation, regularity of services and differentiation of prices and/or quality. On the other hand, the technological factors, for instance, Electronic Data Interchange (EDI), Vessel Traffic System (VTS) and Geographic Information System (GIS) are needed to help information flows between the relevant activities. Reference [20] identified five important criteria for port competitiveness in Chinese ports based on a survey of 180 professionals. The criteria included cargo volume, port facility, port location and service level, and port expenses.

Similarly, [21] identified geographic location, port characteristics and vessel characteristics as factors critical to port selection in evaluating competition among export ports in the United States. Analysing port choices of all import ports in the United States, [22] concludes that distance, transport prices and individual port efficiency play a significant role in determining a port's market share. A survey of shippers [23] identified factors considered to be important port selection criteria in Nigeria. The authors identified three main criteria: efficiency, frequency of ship visits and adequate infrastructure.

Penetration capacity in hinterland has also been noted as an important factor in inter-port competition [24]. Hinterland markets and their access have traditionally been important to ports. A situation may exist whereby a particular port may be solely in the position to provide access to a particular hinterland market thereby giving it total monopoly in the market. On the other hand, a situation may exist whereby many ports within a region may be able to provide access to a common hinterland market thereby creating fierce competition. In this regard, attempting to differentiate between captive and contestable hinterlands, [2] [25] reveal that primary/captive hinterlands are the areas where the port is more established and contestable/secondary hinterlands lie in regions where no single port has a clear cost advantage over competing ports.

\section{Measuring Container Port Competitiveness}

Table 2 shows various methods used by authors in measuring container port competitiveness. 
Table 2. Summary of various methods used in measuring container port competitiveness (source: adapted from [26]).

\begin{tabular}{|c|c|c|}
\hline Method & Authors/studies & Objective \\
\hline \multirow{5}{*}{$\begin{array}{l}\text { Analytic } \\
\text { Hierarchy } \\
\text { Process } \\
\text { (AHP) }\end{array}$} & [20] & Identify factors important to container port competitiveness in China \\
\hline & {$[18]$} & Identify important factors in transshipment port selection \\
\hline & [27] & Identify factors important to shipping lines for choice of port between Montreal and New York \\
\hline & [23] & Identify important port selection factors for shippers in Nigeria \\
\hline & {$[28]$} & Identifying main factors that influence hub port location choice in West Africa \\
\hline \multirow{6}{*}{$\begin{array}{c}\text { Data } \\
\text { Envelopment } \\
\text { Analysis (DEA) }\end{array}$} & [29] & Identify factors affecting efficiency of Portuguese and Greek ports \\
\hline & [30] & Identify factors affecting efficiency of Korean ports \\
\hline & [31] & Identify factors affecting efficiency of container ports \\
\hline & {$[32]$} & $\begin{array}{l}\text { Determine efficiency of ports and impact on competitiveness } \\
\text { of short sea shipping versus road transport in Europe }\end{array}$ \\
\hline & [33] & Determine impact of improving port infrastructure on cargo volumes in two Spanish ports \\
\hline & [6] & Determine efficiency of six West African ports competing for regional hub status \\
\hline \multirow{6}{*}{ Logit Models } & [34] & $\begin{array}{l}\text { Identify factors influencing routing decisions through Rotterdam } \\
\text { compared to other ports in Western Europe }\end{array}$ \\
\hline & {$[16]$} & Identify factors influencing port choice decision of shippers in china \\
\hline & [15] & Identify factors influencing port choice decision of shippers in Taiwan \\
\hline & {$[35]$} & Identify determinants of shipping costs to the U.S. \\
\hline & [21] & Identify factors influencing port choice decision of shippers in the U.S. \\
\hline & [36] & Identify factors influencing routing choice for ports in Western Europe \\
\hline \multirow{2}{*}{$\begin{array}{l}\text { Integer Linear } \\
\text { Programming }\end{array}$} & [37] & Determine impact of variables affecting hub port selection by shipping lines \\
\hline & [38] & $\begin{array}{c}\text { Determine impact of variables affecting hub port selection } \\
\text { by shipping lines in East Coast South America }\end{array}$ \\
\hline \multirow{2}{*}{$\begin{array}{c}\text { Dynamic } \\
\text { Programming }\end{array}$} & [39] & Determine impact of variables influencing port selection for transatlantic liner service network \\
\hline & [40] & $\begin{array}{l}\text { Determine impact of variables affecting hub port selection } \\
\text { based on optimization of cargo routing in China }\end{array}$ \\
\hline $\begin{array}{l}\text { Transshipment } \\
\text { cost functions }\end{array}$ & [41] & Determine impact of transshipment cost on port selection in Northern Europe \\
\hline $\begin{array}{c}\text { Transport } \\
\text { Demand Models }\end{array}$ & [42] & Identify factors influencing port choice behavior of shippers and shipping lines in U.S.A. \\
\hline \multirow{2}{*}{ Cluster Analysis } & [43] & Identify determinants of port competitiveness for Antwerp \\
\hline & [44] & Identify factors affecting competiveness of Dutch maritime cluster \\
\hline Game Theory & [45] & Identify factors affecting competitiveness of supply of port services in South America \\
\hline Oligopolistic Model & [46] & Determine impact of cost competitiveness for container ports in South East Asia. \\
\hline
\end{tabular}

\section{Analytic Hierarchy Process}

The AHP model was developed by Thomas L. Saaty and has been applied to a variety of decision making problems ranging from simple to complex. In particular, AHP has been applied to some maritime transport studies including [18] [20] [23] [27], as noted in Table 2. However, external determinants of port competitiveness outside the scope of port operations are rarely applied in determining the level of port competitiveness. In the case of West Africa, with its volatile political history, the evaluation of projected political stability is important, and highlights the unique nature of this research as applied to port competitiveness in West Africa. Moreover, the application of a political stability index expressly shows how the perceived stability of a country can affect its level of competitiveness and in effect port business in general. 
AHP is a method that can be used to establish and connect both physical and social measures, including cost, time, public acceptance, environmental effects, and so on. In its general form, it is a framework for performing both deductive and inductive thinking. AHP has been noted to provide structure on the decision-making process in addition to providing trade-offs embedded within the decision-making process. Some authors however argue that AHP lacks theoretical basis for constructing hierarchies, hence users can construct different hierarchies for identical situations to produce different results [26].

The AHP considers a set of evaluation criteria, and a set of alternative scenarios among which the best decision is to be made. It generates a weight for each evaluation criterion and scenario according to the information provided by the decision maker. AHP provides a consistent framework to formally incorporate subjective judgments. Their elicitation and subsequent discussion is particularly encouraged in group decision making. The AHP is considered as a powerful and straightforward tool to support such group sessions. A unique feature of the approach is the possibility to compute a measure of inconsistency of the decision makers. This enables them to identify "errors", revise the judgments, and improve the quality of the decision. In using the AHP, one constructs a hierarchy (consisting of goal, criteria and alternatives), and then makes judgments (or performs measurements) on pairs of elements with respect to a controlling element. Ratio scales are derived from these judgments and then synthesized throughout the structure to select the best alternative. The following steps represent the process followed in the multi-criteria evaluation of port competitiveness in West Africa.

- Developing the hierarchy structure with the main goal at the top through to major and then minor criteria.

- Computing the vector of criteria weights and computing the matrix of option scores.

- Ranking the options according the total weights.

\subsection{Developing the Hierarchy Structure}

Figure 3 shows the hierarchical structure of the study with respect to achieving the goal of evaluating port competitiveness.

\subsection{Computing the Vector of Criteria Weights and the Matrix of Option Scores}

A pairwise comparison of elements is produced in each level relative to their importance to an element in the higher level. The procedure requires that a top-down hierarchical approach is observed. Preference matrices are created in the process of comparing elements at a given level and judgments of preference are made on pairs of elements in the structure using the scale in Table 3.

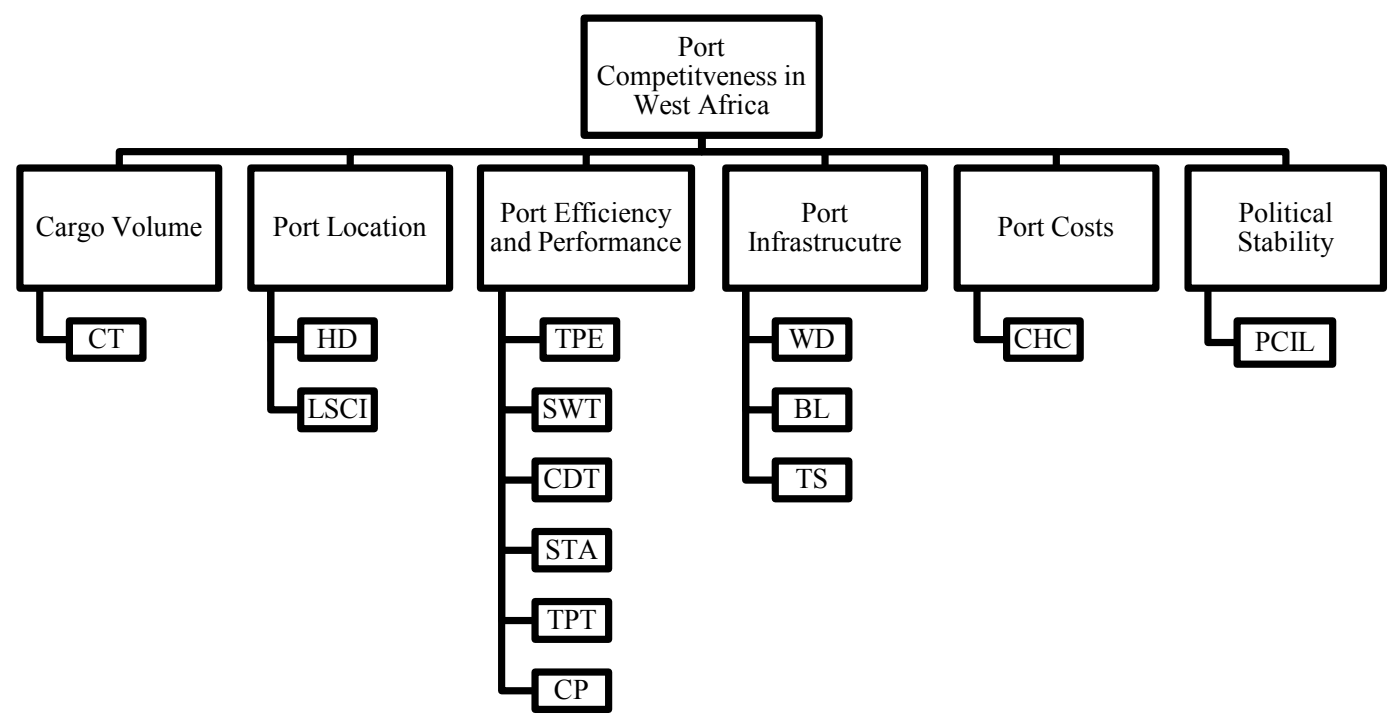

Figure 3. Hierarchical structure of study. CT: Container Throughput; HD: Hinterland Distance; LSCI: Liner Shipping Connectivity Index; TPE: Technical Port Efficiency; SWT: Ship Waiting Time; CDT: Container Dwell Time; STA: Ship Turnaround Time; TPT: Truck Processing Time; CP: Crane Productivity; WD: Water Depth; BL: Berth Length; TS: Terminal Size; CHC: Container Handling Cost; PCIL: Political Conflict and Instability Ledger. 
Table 3. Fundamental scale of the AHP.

\begin{tabular}{cc}
\hline Value & Interpretation \\
\hline 1 & Equal importance \\
2 & Weak importance \\
3 & Moderate importance \\
4 & Moderate importance plus \\
5 & Strong importance \\
6 & Strong importance plus \\
7 & Very strong importance \\
8 & Very strong importance plus \\
9 & Extreme importance \\
\hline
\end{tabular}

Following the work of [20], assume the pairwise comparison matrix $A$. The matrix $A$ is a $n \times n$ real matrix, where $n$ denotes the number of evaluation criteria. Each entry $a_{i j}$ of the matrix is represents the importance of the $i$ th criterion relative to the $j$ th criterion and is formed by comparing the row element $A_{i}$ with the column element $A_{j}$ : The number of criteria $n$ is $A_{1}, \cdots, A_{n}$ and when the original weights for them are $w_{1}, \cdots, w_{n}$ the relative comparative value of the weights of $A_{i}$ and $A_{j}, a_{i j}$ satisfy the formula:

$$
a_{i j}=\frac{w_{i}}{w_{j}}
$$

The relative weights are derived for various elements and are computed with respect to elements in a higher level of the hierarchy, as the components of the normalized eigenvector associated with the largest Eigenvalue of their comparison matrices. If $\mathrm{n}$ is the number of elements to be compared, then decision makers will make pairwise comparisons $\frac{n(n-1)}{2}$ times.

The values of the pairwise comparisons in the AHP are determined according to a scale with values which can be found in Table 3. The pairwise comparison matrices are in the form:

$$
A=\left[\begin{array}{ccc}
a_{11} & \cdots & a_{1 n} \\
\vdots & \ddots & \vdots \\
a_{n 1} & \cdots & a_{n n}
\end{array}\right]=\left[\begin{array}{ccc}
w_{1} / w_{1} & \cdots & w_{1} / w_{n} \\
\vdots & \ddots & \vdots \\
w_{n} / w_{1} & \cdots & w_{n} / w_{n}
\end{array}\right]
$$

Matrix $A$ is multiplied by the vector of numerical weights (w), and vector $n \cdot w$ is obtained.

$$
A=\left[\begin{array}{cccc}
w_{1} / w_{1} & w_{1} / w_{2} & \cdots & w_{1} / w_{n} \\
w_{2} / w_{1} & w_{2} / w_{2} & \cdots & w_{2} / w_{n} \\
\vdots & \vdots & \ddots & \vdots \\
w_{n} / w_{1} & w_{n} / w_{2} & \cdots & w_{n} / w_{n}
\end{array}\right]\left[\begin{array}{c}
w_{1} \\
w_{2} \\
\vdots \\
w_{n}
\end{array}\right]=n\left[\begin{array}{c}
w_{1} \\
w_{2} \\
\vdots \\
w_{n}
\end{array}\right]
$$

Equation (3) can be expressed in the form:

$$
A \times w=n \times w
$$

The formula can be transformed into the form:

$$
(A-n \cdot I) \cdot w=0
$$

Sincew is unknown, to find $A$ for this non-zero equation, an eigenvalue equation is used.

$w^{\prime}$ is obtained from computing pair-comparison matrices formed from the respondents answers. Since the sum of the eigenvalues of a positive matrix is equal to the trace of the matrix, the non-zero eigenvalue has the value of $n$, the size of the matrix. This Eigenvalue is referred to as $\lambda_{\max }$.

$$
A^{\prime} \cdot w^{\prime}=\lambda_{\max } \cdot w^{\prime}
$$

where, $w^{\prime}$ is normalized eigenvector, $\lambda_{\max }$ is the principal eigenvalue for $A^{\prime}$. 
The AHP incorporates an effective technique for checking consistency as in reality the more complex a problem is the more difficult it is to expect consistent answers from respondents/decision-makers. This technique involves the computation of a suitable Consistency Index (CI). Perfectly consistent decision maker should obtain $\mathrm{CI}=0$, although small values of inconsistency may be tolerated. Generally, if the $\mathrm{CI}<0.10$, the consistency of the decision maker is acceptable (Table 4).

$$
\mathrm{CI}=\frac{\lambda_{\max }^{\prime}-n}{n-1}
$$

The Consistency Ratio (CR) can also be used for checking consistency. If Consistency Ratio $(\mathrm{CR}) \leq 0.1$, the solution to weights are acceptable.

$$
\mathrm{CR}=\frac{\mathrm{CI}}{M}
$$

\subsection{Ranking of Options}

The composite weights of the decision alternatives are determined by aggregating the weights throughout the hierarchy. This is done by following a path from the top of the hierarchy to each alternative at the lowest level and multiplying the weights along each segment of the path. The outcome of this aggregation is a normalized vector of the overall weights of the options. The option with the highest overall weight is ranked highest and so on.

\section{Data and Analysis}

This paper focuses on relevant elements that impact port competitiveness in West Africa. The applicable variables and data were collated through a series of surveys through a group of experts in the port and shipping profession in West Africa. Experts were purposively selected and comprise a total of 65 ship owners and agents, terminal operators, shippers, academic and research professionals in West Africa. The surveys were conducted through face-to-face interviews, by telephone, and through email. Out of the 65 potential interviewees, 52 responses were successfully collected. The respondents were first required to select critical factors (major criteria) from a list of factors that had been collated from literature. After the critical factors were collated and ranked, sub-criteria were selected and ranked according to their importance to port competitiveness in West Africa.

\subsection{Data}

The data used in the evaluation was collated from various sources for the base year of 2012. Table 5 shows the various data used based on major and sub-criteria as applied to each port.

\subsubsection{Cargo Volume}

One of the most important factors that express port competitiveness is the amount of cargo that passes through the port (cargo throughput). Ports are primarily compared by the amount of cargo they handle in a specified period and port users find ports that handle more cargo preferable. For this study, container throughput is assessed as a sub-criterion and includes imports, exports and transshipment containers in TEU. In the West Africa countries concerned, container throughput has been increasing at an average rate of 10\% per annum from 2003-2012. From the data, it is clear that Lagos handles the most containers (1,623,141 TEUs) in the base year 2012; almost 6 times more than Lomé which handles the least (288,481 TEUs). Lagos is closely followed by Tema (884,984 TEUs), then Abidjan (668,065.43 TEUs), Dakar (383,902.65 TEUs) and then Cotonou (348,190.37 TEUs).

\subsubsection{Location of Port}

The location of a port is also an important consideration to evaluate competitiveness in West Africa as a port's

Table 4. Random consistency index.

\begin{tabular}{cccccccccccccccc}
\hline $\boldsymbol{n}$ & 1 & 2 & 3 & 4 & 5 & 6 & 7 & 8 & 9 & 10 & 11 & 12 \\
$\boldsymbol{M}$ & 0.00 & 0.00 & 0.58 & 0.90 & 1.12 & 1.24 & 1.32 & 1.41 & 1.45 & 1.49 & 1.51 & 1.53 \\
\hline
\end{tabular}


Table 5. Various criteria for evaluating port competitiveness in West Africa (source: [6] [47] [48]).

\begin{tabular}{|c|c|c|c|c|c|c|c|}
\hline \multirow{2}{*}{ Major criteria } & \multirow{2}{*}{ Sub-criteria } & \multicolumn{6}{|c|}{ Ports } \\
\hline & & Dakar & Abidjan & Tema & Lomé & Cotonou & Lagos \\
\hline Cargo volume & Container throughput (TEUs) & 383902.65 & 668065.43 & 884984.00 & 288481.00 & 348190.37 & 1623141.00 \\
\hline \multirow{4}{*}{ Port location } & Hinterland distance $(\mathrm{Km})$ & 2075.33 & 1237.67 & 1181.00 & 1271.67 & 1311.33 & 1375.67 \\
\hline & $\begin{array}{l}\text { Liner shipping } \\
\text { connectivity Index }\end{array}$ & 13.60 & 16.50 & 17.90 & 14.10 & 15.00 & 21.80 \\
\hline & Technical port efficiency & 0.62 & 0.90 & 0.91 & 0.88 & 0.46 & 0.76 \\
\hline & $\begin{array}{c}\text { Average container } \\
\text { ship waiting time (days) }\end{array}$ & 18.00 & 1.00 & 12.35 & 1.00 & 24.00 & 12.00 \\
\hline \multirow{5}{*}{$\begin{array}{c}\text { Port } \\
\text { efficiency } \\
\text { and } \\
\text { performance }\end{array}$} & $\begin{array}{l}\text { Average Container } \\
\text { dwell time (days) }\end{array}$ & 7.00 & 12.00 & 25.00 & 13.00 & 12.00 & 42.00 \\
\hline & Ship turnaround time (hours) & 24.00 & 1.00 & 32.00 & 1.00 & 24.00 & 12.00 \\
\hline & Truck processing time (hours) & 5.00 & 2.50 & 8.00 & 4.00 & 6.00 & 6.00 \\
\hline & $\begin{array}{l}\text { Crane productivity } \\
\text { (moves per hour) }\end{array}$ & 20.00 & 18.00 & 20.00 & 18.00 & 18.00 & 15.00 \\
\hline & water depth (m) & 11.50 & 15.00 & 11.50 & 14.00 & 10.00 & 9.00 \\
\hline \multirow[t]{2}{*}{$\begin{array}{c}\text { Port } \\
\text { infrastructure }\end{array}$} & berth length $(m)$ & 660.00 & 1000.00 & 574.00 & 430.00 & 540.00 & 1005.00 \\
\hline & terminal size (ha) & 35.00 & 34.00 & 10.00 & 12.00 & 20.00 & 55.00 \\
\hline Port costs & Container handling cost (US \$) & 160.00 & 260.00 & 168.00 & 220.00 & 180.00 & 155.00 \\
\hline $\begin{array}{l}\text { Political } \\
\text { stability }^{*}\end{array}$ & $\begin{array}{l}\text { Peace and Conflict } \\
\text { Instability Ledger }\end{array}$ & 8.00 & 7.70 & 6.50 & 5.40 & 12.20 & 20.70 \\
\hline
\end{tabular}

*Political stability criteria was introduced by the authors although it was not in the original list of variables as most shipping lines were concerned with the impact of political stability issues in the region on port business.

location along major shipping trade routes and its location from its main hinterland market determine its attractiveness. The attributes to be considered under port location which represent both seaside and landside importance of location are the port's distance from the main hinterland and the port's Liner Shipping Connectivity Index (LSCI). To achieve uniformity in the analysis, contestable hinterlands of landlocked West Africa have been chosen by calculating the average distance from each port to the various landlocked capitals or commercial centres. The landlocked countries include Mali, Niger and Burkina Faso in Sahelian West Africa. The Port of Tema has the least mean distance $(1181 \mathrm{~km})$ from the hinterland whilst Dakar at the western-most point of West Africa has the highest mean distance of $2075 \mathrm{~km}$. The LSCI which captures how well countries are connected to global shipping networks showed Lagos, Tema and Abidjan occupying the first three positions respectively.

\subsubsection{Port Efficiency and Performance}

Port efficiency and performance are factors of the service level of a port. The higher the quality of service provided to port users, the higher the competitiveness of the port. The attributes to be considered include technical port efficiency, ship waiting time, container dwell time, ship turnaround time, crane productivity and truck processing time. These factors represent ship-to-shore and terminal efficiency of port productivity and directly influence the efficiency of shipping companies and other port users. Technical Port Efficiency for each port has been determined by an earlier study (see [6]) using the Data Envelopment Analysis (DEA) method. Tema, Abidjan and Lomé ranked first, second and third with efficiencies of $91 \%, 90 \%$ and $88 \%$ respectively. Cotonou obtained the least efficiency score with $46 \%$. The other factors which are indicative of performance show that ports which provide services in a timely manner outperform ports that do not.

\subsubsection{Port Infrastructure}

The better the infrastructure of a port the higher its level of competitiveness as the level of port infrastructure affects the level of service ports provide to users. Ports that are able to accommodate more and larger vessels at 
a given period of time are deemed more competitive. Port infrastructure also has a large role to play in reducing port congestion that plagues most West African ports. Therefore, the attributes to be assessed include water depth (permissible drafts for vessels under full load), linear berth length and terminal size. Particularly, deeper drafts, longer berths and larger terminal areas indicate a port with better infrastructure. Lagos and Abidjan have the two largest terminal sizes (55 and 34 hectares respectively) and berth lengths (1005 and 1000 metres respectively). However, in terms of draft, Lagos has the shallowest (9 metres) restricting the size of vessels that can enter the port with Abidjan having the deepest of 15 metres.

\subsubsection{Port Costs}

Port costs represent the financial aspect of competitiveness and generally impact supply chain costs. Port users are therefore drawn to ports that offer competitive rates for the provision of port services. The lower the rate, the more competitive the port is adjudged. In this study, container handling cost is the sole attribute assessed as other costs and codes of practice are quite different amongst the countries under study. Lagos, Dakar and Tema have the lowest handling cost $(\$ 155, \$ 160$ and $\$ 168)$ respectively with Abidjan charging the highest rate $(\$ 260)$ which is twice the global benchmark.

\subsubsection{Political Stability}

Political stability is key to successful port business and therefore the competitive position of ports. During periods of instability ports usually suffer from disruption and delays to port business. Cargo operations may be halted and shippers may incur significant demurrage liabilities. Therefore, port users find ports in countries of stable political environment more preferable, and thus more competitive. In this study, the authors have used the Peace and Conflict Instability Ledger (PCIL) to evaluate political stability of the ports under study. The PCIL ranks states according to their forecasted risk of future political instability. From the data, Lagos attains the worst (20.7) stability index with Lomé attaining the best (5.4).

\subsection{Multi-Criteria Evaluation of Port Competitiveness}

The weights of major criteria were computed by comparing each pair of elements by the group of experts as such knowledge is not common to the general public. The values used in the comparison are indicated by numbers ranging from $1-9$, as explained in the methodology section. Table 6 shows the pairwise comparison and weights of the major criteria as collated from the respondents. Particularly, ship-owners/agents were more concerned with political stability and port efficiency and performance whiles shippers were concerned with port location and port costs.

Based on the survey, Port efficiency and performance was prioritized first (0.4975), followed by Political stability (0.2348), Port costs and Port infrastructure were ranked third (0.0954 each), Port location and Cargo volume were ranked fifth $(0.0385$ each). The Consistency Ratio was 0.013 which confirmed that the results of the survey were consistent and reliable.

The survey also revealed the critical success factors for port competitiveness in West Africa at the sub-criteria level. These factors were then ranked and the global weights obtained by multiplying the local weights by the

\begin{tabular}{|c|c|c|c|c|c|c|c|c|}
\hline Major criteria & $\begin{array}{c}\text { Cargo } \\
\text { volume }\end{array}$ & $\begin{array}{c}\text { Port } \\
\text { location }\end{array}$ & $\begin{array}{c}\text { Port efficiency } \\
\text { and performance }\end{array}$ & $\begin{array}{c}\text { Port } \\
\text { infrastructure }\end{array}$ & $\begin{array}{l}\text { Port } \\
\text { costs }\end{array}$ & $\begin{array}{l}\text { Political } \\
\text { stability }\end{array}$ & Weight & Rank \\
\hline Cargo volume & 1 & 1 & $1 / 9$ & $1 / 3$ & $1 / 3$ & $1 / 6$ & 0.0385 & 5 \\
\hline Port location & 1 & 1 & $1 / 9$ & $1 / 3$ & $1 / 3$ & $1 / 6$ & 0.0385 & 5 \\
\hline $\begin{array}{l}\text { Port efficiency } \\
\text { and performance }\end{array}$ & 9 & 9 & 1 & 6 & 6 & 3 & 0.4975 & 1 \\
\hline Port infrastructure & 3 & 3 & $1 / 6$ & 1 & 1 & $1 / 3$ & 0.0954 & 3 \\
\hline Port costs & 3 & 3 & $1 / 6$ & 1 & 1 & $1 / 3$ & 0.0954 & 3 \\
\hline Political stability & 6 & 6 & $1 / 3$ & 3 & 3 & 1 & 0.2348 & 2 \\
\hline
\end{tabular}


weights of the major criteria for each category. PCIL (0.235), crane productivity $(0.142)$ and technical port efficiency $(0.142)$ received the highest weights and are the three most critical factors for port competitiveness in West Africa. At the bottom of Table 7 is LSCI with a global weight of $0.01(1 \%)$. Consistent with the ranking of major criteria, the second to fourth ranked sub-criteria are factors of port efficiency and performance. Hinterland distance is ranked 9th with a global weight of 0.029 .

The main reason for adopting this method was to evaluate port competitiveness in West Africa. Considering the results in Table 8, Abidjan Port emerges the most competitive port (0.2319) in West Africa followed

\section{Table 7. Priority order of Sub-criteria.}

\begin{tabular}{ccc}
\hline Rank & Critical success factors (sub-criteria) & Global weights \\
\hline 1 & Peace and Conflict Instability Ledger (PCIL) & 0.2348 \\
2 & Crane Productivity & 0.1418 \\
3 & Technical Port Efficiency & 0.1418 \\
4 & Ship Turnaround Time & 0.1305 \\
5 & Handling Cost & 0.0954 \\
6 & Water depth & 0.0620 \\
7 & Ship Waiting Time & 0.0418 \\
8 & Container throughput & 0.0385 \\
9 & Hinterland distance & 0.0289 \\
10 & Truck Processing Time & 0.0234 \\
11 & Container Dwell Time & 0.0234 \\
12 & Berth length & 0.0191 \\
13 & Terminal Size & 0.0143 \\
\hline
\end{tabular}

Table 8. Ranking of ports according to evaluation.

\begin{tabular}{|c|c|c|c|c|c|c|c|}
\hline \multirow{2}{*}{ Major criteria } & \multirow{2}{*}{ Sub-criteria } & \multicolumn{6}{|c|}{ Ports } \\
\hline & & Dakar & Abidjan & Tema & Lomé & Cotonou & Lagos \\
\hline Cargo volume & Container throughput & 0.003 & 0.005 & 0.003 & 0.004 & 0.002 & 0.021 \\
\hline \multirow{4}{*}{ Port location } & Hinterland distance & 0.001 & 0.004 & 0.010 & 0.005 & 0.004 & 0.005 \\
\hline & $L S C I$ & 0.0004 & 0.001 & 0.002 & 0.001 & 0.001 & 0.005 \\
\hline & Port Efficiency & 0.007 & 0.039 & 0.039 & 0.035 & 0.004 & 0.017 \\
\hline & $S W T$ & 0.002 & 0.016 & 0.004 & 0.014 & 0.001 & 0.005 \\
\hline \multirow{5}{*}{$\begin{array}{l}\text { Port efficiency and } \\
\text { performance }\end{array}$} & $C D T$ & 0.006 & 0.005 & 0.002 & 0.005 & 0.005 & 0.001 \\
\hline & $S T T$ & 0.006 & 0.045 & 0.004 & 0.049 & 0.006 & 0.020 \\
\hline & $T P T$ & 0.003 & 0.011 & 0.001 & 0.003 & 0.003 & 0.003 \\
\hline & Crane Productivity & 0.048 & 0.014 & 0.048 & 0.014 & 0.014 & 0.003 \\
\hline & Water depth & 0.006 & 0.027 & 0.006 & 0.018 & 0.003 & 0.002 \\
\hline \multirow[t]{2}{*}{ Port infrastructure } & Berth length & 0.002 & 0.007 & 0.001 & 0.001 & 0.001 & 0.007 \\
\hline & Terminal Size & 0.003 & 0.002 & 0.001 & 0.001 & 0.001 & 0.007 \\
\hline Port costs & Handling cost & 0.026 & 0.003 & 0.020 & 0.003 & 0.012 & 0.032 \\
\hline Political stability & PCIL & 0.042 & 0.052 & 0.052 & 0.063 & 0.020 & 0.006 \\
\hline \multicolumn{2}{|c|}{ Total } & 0.1558 & 0.2319 & 0.1917 & 0.2146 & 0.0773 & 0.1344 \\
\hline \multicolumn{2}{|c|}{ Rank per priorities } & $4^{\text {th }}$ & $1^{\text {st }}$ & $3^{\text {rd }}$ & $2^{\text {nd }}$ & $6^{\text {th }}$ & $5^{\text {th }}$ \\
\hline
\end{tabular}


by Lomé (0.2146), Tema (0.1917), Dakar (0.1558), Lagos (0.1344) and Cotonou (0.0773). Abidjan's PCIL, ship turnaround time and port efficiency scores are its strongest links with LSCI being its weakest link even though the port's connection to global shipping networks is the third best in West Africa. Comparatively, the Port of Abidjan's port efficiency and performance, and port infrastructure are the best in West Africa. The port provides the best service level to port users (shipping lines) by providing quick access to berths on ship arrival and a quick ship turnaround time. This allows containerships to spend very little time in port and reduce their overall operating costs. Although Abidjan charges the most in terms of container handling, the port's crane productivity is relatively quite poor only better than that of Lagos. The average distance from the Port of Abidjan to the hinterlands of landlocked West Africa is only second best to the Port of Tema which is quite understandable as Ivory Coast and Ghana are neighboring coastal states. Despite recent political turmoil, Ivory Coast's political stability outlook is quite decent and as such does not negatively affect its final score.

In terms of scale, the Port of Lomé is the smallest but can accommodate large ships due to its deep draft (14m). The port's efficiency and performance in serving vessels is good but handling costs are relatively high. However, Lomé's PCIL and crane productivity scores were relatively high and are its strongest links. Alternatively, Tema's strongest links are its political stability, crane productivity, and port efficiency and performance. The port's handling cost is also quite competitive. The port however suffers from long ship turnaround times which may reduce its marketability to shipping lines and is probably a result of congestion as the scale of the port to the amount of cargo it handles is quite unbalanced. Tema's crane productivity is highest along with the Port of Dakar, and in terms of location, Tema seems best suited to service the landlocked hinterland of West Africa.

The Port of Dakar, adjudged fourth in the ranking has the best crane productivity and one of the cheapest handling costs but its major drawback is the distance from the port to the landlocked West African hinterland. Its technical port efficiency is also quite low with a rather average throughput for a port of its scale. Dakar's political stability score was third highest but was one of its strongest links in addition to its crane productivity. Lagos (fifth in rank) is a largest port in West Africa serving the largest economy in Africa (Nigeria). The port obviously handles the most containerized cargo in West Africa which is mostly meant for the domestic market. In terms of port infrastructure, the Lagos Port Complex has the longest berth and the largest terminal area. This would have been ideal in accommodating bigger ships and more containers but the port's water depth is comparatively the worst $(9 \mathrm{~m})$. This implies that the port can only accommodate vessels no larger than 2000 TEUs. This is the major drawback of the port. In terms of costs, the port charges the cheapest handling cost but also provides the worst crane productivity amongst the ports under study. In terms of the port's connectivity to global shipping networks, as the largest economy in Africa it is only natural that Lagos has the highest connectivity score as the port accounts for about $39 \%$ of TEUs amongst the lot in 2012. Lagos' political stability and port efficiency and performance are its weakest links. The port's political stability score is the lowest due to the ongoing terrorist insurgency in the north of the country.

The Port of Cotonou, Lagos' neighbor to the West is the least competitive port in West Africa amongst the ports evaluated. Its weakest links are its cargo volume and its port efficiency and performance. In particular, its handling cost and its crane productivity are its strongest links and are quite competitive. The port's political stability score is quite low and may be as a result of political instability in its neighbor Nigeria that could spill over into its territory.

\section{Conclusions}

The aim of this paper was to evaluate the competitiveness of major ports in West Africa. The process of evaluation involved reviewing relevant literature with respect to port competitiveness and the methods used in their evaluation. From a list compiled from existing literature, major criteria and sub-criteria for evaluating port competitiveness in West Africa were selected by a group of experts purposively selected by the authors. A hierarchy of factors was constructed and the influence of each alternative was prioritized. This paper is quite unique as it also takes the political stability of the ports' environment into consideration and has shown that political stability does have a huge impact on competitiveness of ports in the West African region. However, the drawbacks of this research lie in the basic characteristics of the AHP model, as some authors have argued that AHP lacks theoretical basis for constructing hierarchies; hence, users can construct different hierarchies for identical situations to produce different results. Based on data for the base year of 2012, each criterion and sub-criterion were 
evaluated with respect to the ports under study. From the above results, port efficiency and performance were the most important criterion for evaluating port competiveness, followed by political stability, port costs and port infrastructure in third positions each, and port location and cargo volume both in fifth.

The study revealed that the Port of Abidjan was the most competitive port in West Africa noting its port efficiency and performance and port infrastructure as the best. In order to increase its competitiveness further, the port may have to look at its pricing structure as it charges the most in terms of container handling (\$260 per TEU) way above the global benchmark in 2012. The port may also need to take steps in increasing its crane productivity by either increasing the number of ship-to-shore cranes in use or providing more training to its crane handlers. This recommendation also applied to the Port of Lomé which was adjudged second in the ranking with its good port infrastructure and political stability but its high handling costs. The Ports of Tema and Dakar attained third and fourth positions respectively and were quite suited to match Abidjan in terms of competitiveness. In order to be more competitive, Tema needs to invest in dredging its port including access channels to accommodate larger ships and generally increase its performance and ultimately service levels. Too much time is spent in processing trucks, and container dwell times and ship turnaround times are too long. These factors affect its marketability and in effect its competitiveness. The distance from Dakar to landlocked hinterland of West Africa is its major drawback but investment in efficient cross-border inland transport networks from the port to the hinterland my increase its competitiveness. There is also substantial waste in the use of the ports resources evidenced by its low technical port efficiency score. However, the port's pricing structure is very competitive.

In order to be more competitive, the Port of Lagos also needs to invest in dredging in order to accommodate larger ships. As with Tema, its port efficiency and performance is poor requiring processes at the port to be streamlined in order to provide better service levels to port users. It must be noted that from the authors' analysis, without the political stability criterion, Lagos port will have been one of the most competitive ports, either placing second or third. The Port of Cotonou finds itself stuck in-between competitive neighboring ports to both the east and the west. Cotonou finds itself next to Lagos, the largest port in terms of scale (but the least politically stable) and relatively efficient ports to the east in Lomé, Tema and Abidjan. The port is also unfortunate to have political instability to the east affecting its evaluation. Nonetheless, in order to be more competitive, Cotonou may seek to employ a price differentiation strategy and increase its port efficiency and performance in order to increase its attractiveness to port users. Based on distance, Cotonou is also quite suitably placed to handle cargo for the hinterland as its distance from the hinterland is quite suitable.

\section{References}

[1] World Bank (2007) World Bank Port Reform Toolkit: The Evolution of Ports in a Competitive World. http://www.ppiaf.org/sites/ppiaf.org/files/documents/toolkits/Portoolkit/Toolkit/pdf/modules/02_TOOLKIT_Module2. pdf

[2] De Langen, P.W. (2007) Port Competition and Selection in Contestable Hinterlands; the Case of Austria. European Journal of Transport and Infrastructure Research, 7, 1-14.

[3] Van de Voorde, E. and Vaneslander, T. (2009) Market Power and Vertical and Horizontal Integration in the Maritime Shipping and Port Industry. Discussion Paper, JTRC, OECD/ITF, 2.

[4] Vanelslander, T. (2005) The Economics behind Co-Operation and Competition in Sea-Port Container Handling. Ph.D. Thesis, University of Antwerp, Antwerp.

[5] vanDyck, G.K. (2015) The Drive for a Regional Hub Port for West Africa: General Requirements and Capacity Forecast. International Journal of Business and Economics Research, 4, 36-44. http://dx.doi.org/10.11648/j.ijber.20150402.13

[6] van Dyck, G.K. (2015) Assessment of Port Efficiency in West Africa Using Data Envelopment Analysis (DEA). American Journal of Industrial and Business Management, 5, 208-218. http://dx.doi.org/10.4236/ajibm.2015.54023

[7] MLTC/CATRAM (2013) Market Study on Container Terminals in West and Central Africa. Maritime Logistics and Trade Consulting/Catram Consultants, Paris.

[8] Porter, M. (1990) The Competitive Advantage of Nations. Harvard Business Review, 68, 73-93. http://dx.doi.org/10.1002/cir.3880010112

[9] Van de Voorde, E. and Winkelmans, W. (2002) A General Introduction to Port Competition and Management. In: Huybrechts et al., Eds., Port Competitiveness (Ed. De Boeck, Antwerp), Ed. De Boeck, Antwerp, 1-16.

[10] Slack, B. (1985) Containerization and Inter-Port Competition. Maritime Policy and Management, 12, 293-304. 
http://dx.doi.org/10.1080/03088838500000043

[11] D'Este, G. and Meyrick, S. (1992) Carrier Selection in a RO/RO Ferry Trade Part 1. Decision Factors and Attitudes. Maritime Policy and Management, 19, 115-126. http://dx.doi.org/10.1080/03088839200000019

[12] Rimmer, P.J. (1998) Ocean Liner Shipping Services: Corporate Restructuring and Port Selection/Competition. Asia Pacific Viewpoint, 39, 193-208. http://dx.doi.org/10.1111/1467-8373.00063

[13] Chang, S. (2000) Disasters and Transport Systems: Loss, Recovery and Competition at the Port of Kobe after the 1995 Earthquake. Journal of Transport Geography, 8, 53-65. http://dx.doi.org/10.1016/S0966-6923(99)00023-X

[14] Heaver, T., Meersman, H. and van de Voorde, E. (2001) Cooperation and Competition in International Container Transport: Strategies for Ports. Maritime Policy and Management, 28, 293-305. http://dx.doi.org/10.1080/03088830110055693

[15] Nir, A., Lin, K. and Liang, G. (2003) Port Choice Behavior-From the Perspective of the Shipper. Maritime Policy and Management, 30, 165-173. http://dx.doi.org/10.1080/0308883032000069262

[16] Tiwari, P., Itoh, H. and Doi, M. (2003) Shippers' Port and Carrier Selection Behavior in China: A Discrete Choice Analysis. Maritime Economics and Logistics, 5, 23-39. http://dx.doi.org/10.1057/palgrave.mel.9100062

[17] Ha, M.S. (2003) A Comparison of Service Quality at Major Container Ports: Implications for Korean Ports. Journal of Transport Geography, 11, 131-137. http://dx.doi.org/10.1016/S0966-6923(02)00069-8

[18] Lirn, T., Thanopoulou, H., Beynon, M. and Beresford, A. (2004) An Application of AHP on Transshipment Port Selection: A Global Perspective. Maritime Policy \& Management, 35, 395-409.

[19] Perez-Labajos, C. and Blanco, B. (2004) Competitive Policies for Commercial Sea Ports in the EU. Marine Policy, 28, 553-556. http://dx.doi.org/10.1016/j.marpol.2004.05.003

[20] Song, D.-W. and Yeo, K.-T. (2004) A Competitive Analysis of Chinese Container Ports Using the Analytic Hierarchy Process. Maritime Economics and Logistics, 6, 34-52. http://dx.doi.org/10.1057/palgrave.mel.9100096

[21] Malchow, M. and Kanafani, A. (2004) A Disaggregate Analysis of Port Selection. Transportation Research Part E, 40, 317-337. http://dx.doi.org/10.1016/j.tre.2003.05.001

[22] Blonigen, B. and Wilson, W. (2006) International Trade, Transportation Networks and Port Choice Manuscript. University of Oregon, Eugene.

[23] Ugboma, C., Ugboma, O. and Ogwude, I. (2006) An Analytic Hierarchy Process (AHP) Approach to Port Selection Decisions-Empirical Evidence from Nigerian Ports. Maritime Economics and Logistics, 8, 251-266. http://dx.doi.org/10.1057/palgrave.mel.9100160

[24] Ferrari, C., Parola, F. and Gattorna, E. (2011) Measuring the Quality of Port Hinterland Accessibility: The Ligurian Case. Transport Policy, 18, 382-391. http://dx.doi.org/10.1016/j.tranpol.2010.11.002

[25] Morgan, W. (1951) Observations on the Study of Hinterlands in Europe. Tijdschrift Sociale en Economische Geografie, 42, 366-337.

[26] Yap, W. (2009) Container Shipping Services and Their Impact on Container Port Competitiveness. University Press Antwerp, Antwerp.

[27] Guy, E. and Urli, B. (2006) Port Selection and Multicriteria Analysis: An Application to the Montreal-New York Alternative. Maritime Economics and Logistics, 8, 169-186. http://dx.doi.org/10.1057/palgrave.mel.9100152

[28] Alanda, A.M. and Yang, Z. (2013) Hub-Port Choice in West Africa. International Forum on Shipping, Ports and Airports (IFSPA) 2013: Trade, Supply Chain Activities and Transport: Contemporary Logistics and Maritime Issues, Hong Kong, October 2013, 405-413.

[29] Barros, C.P. and Athanassiou, M. (2004) Efficiency in European Seaports with DEA: Evidence from Greece and Portugal. Maritime Economics and Logistics, 6, 122-140. http://dx.doi.org/10.1057/palgrave.mel.9100099

[30] Park, R.-K. and De, P. (2004) An Alternative Approach to Efficiency Measurement of Seaports. Maritime Economics and Logistics, 6, 53-69. http://dx.doi.org/10.1057/palgrave.mel.9100094

[31] Cullinane, K., Song, D.-W., Ji, P. and Wang, T.-F. (2005) The Relationship between Privatization and DEA Estimates of Efficiency in the Container Port Industry. Journal of Economics and Business, 57, 433-462. http://dx.doi.org/10.1016/j.jeconbus.2005.02.007

[32] Trujillo, L. and Tovar, B. (2007) The European Port Industry: An Analysis of Its Economic Efficiency. Maritime Economics and Logistics, 9, 148-171. http://dx.doi.org/10.1057/palgrave.mel.9100177

[33] Garcia-Alonso, L. and Martin-Bofarull, M. (2007) Impact of Port Investment on Efficiency and Capacity to Attract Traffic in Spain: Bilbao versus Valencia. Maritime Economics and Logistics, 9, 254-267. http://dx.doi.org/10.1057/palgrave.mel.9100183

[34] Veldman, S. and Buckmann, E. (2003) A Model on Container Port Competition: An Application for the West Euro- 
pean Container Hub-Ports. Maritime Economics and Logistics, 5, 3-22. http://dx.doi.org/10.1057/palgrave.mel.9100058

[35] Clark, X., Dollar, D. and Micco, A. (2004) Port Efficiency, Maritime Transport Costs and Bilateral Trade. Journal of Development Economics, 75, 417-450. http://dx.doi.org/10.1016/j.jdeveco.2004.06.005

[36] Veldman, S., Buckmann, E. and Saitua, R. (2005) River Depth and Container Port Market Shares: The Impact of Deepening the Scheldt River on the West European Container Hub-Port Market Shares. Maritime Economics and Logistics, 7, 336-355. http://dx.doi.org/10.1057/palgrave.mel.9100142

[37] Mourao, M., Pato, M. and Paixao, A. (2002) Ship Assessments with Hub and Spoke Constraints. Maritime Policy and Management, 29, 135-150. http://dx.doi.org/10.1080/03088830110078364

[38] Aversa, R., Botter, R., Haralambides, H. and Yoshiazaki, H. (2005) A Mixed Integer Programming Model on the Location of a Hub Port in the East Coast of South America. Maritime Economics and Logistics, 7, 1-18. http://dx.doi.org/10.1057/palgrave.mel.9100121

[39] Ting, S. and Tzeng, G. (2003) Ship Scheduling and Cost Analysis for Route Planning in Liner Shipping. Maritime Economics and Logistics, 5, 378-392. http://dx.doi.org/10.1057/palgrave.mel.9100087

[40] Zeng, Z. and Yang, Z. (2002) Dynamic Programming of Port Position and Scale in the Hierarchised Container Ports Network. Maritime Policy and Management, 29, 163-177. http://dx.doi.org/10.1080/03088830110113599

[41] Baird, A. (2002) The Economics of Container Transshipment in Northern Europe. International Journal of Maritime Economics, 4, 249-280. http://dx.doi.org/10.1057/palgrave.ijme.9100048

[42] Luo, M. and Grigalunas, T. (2003) A Spatial-Economic Multimodal Transportation Simulation Model for US Container Coastal Ports. Maritime Economics and Logistics, 5, 158-178. http://dx.doi.org/10.1057/palgrave.mel.9100067

[43] Haezendonck, E., Pison, G., Rousseeuw, P., Struyf, A. and Verbeke, A. (2000) The Competitive Advantage of Seaports. International Journal of Maritime Economics, 2, 69-82. http://dx.doi.org/10.1057/ijme.2000.8

[44] de Langen, P. (2002) Clustering and Performance: The Case of Maritime Clustering in the Netherlands. Maritime Policy and Management, 29, 209-221. http://dx.doi.org/10.1080/03088830210132605

[45] Flor, L. and Defilippi, E. (2003) Port Infrastructure: An Access Model for the Essential Facility. Maritime Economics and Logistics, 5, 116-132. http://dx.doi.org/10.1057/palgrave.mel.9100075

[46] Yap, W. and Lam, J. (2006) A Measurement and Comparison of Cost Competitiveness of Container Ports in South East Asia. Transportation, 33, 641-654. http://dx.doi.org/10.1007/s11116-006-7474-4

[47] Center for International Development and Conflict Management (2012) Peace and Conflict 2012. Paradigm Publishers, University of Maryland, College Park.

[48] Gwilliam, K. (2011) Africa's Transport Infrastructure: Mainstreaming Maintenance and Management. The World Bank, Washington DC. http://dx.doi.org/10.1596/978-0-8213-8456-5 